Island Studies Journal, Vol. 8, No. 1, 2013, pp. 67-83

\title{
Tuvalu, Sovereignty and Climate Change: Considering Fenua, the Archipelago and Emigration
}

Elaine Stratford

University of Tasmania

Australia

Elaine.Stratford@utas.edu.au

Carol Farbotko

University of Wollongong

New South Wales, Australia

carol.farbotko@gmail.com

Heather Lazrus

National Center for Atmospheric Research

Boulder CO, USA

hlazrus@ucar.edu

\begin{abstract}
Tuvalu is a Pacific atoll nation-state that has come to stand for predicaments implicating climate change, forced emigration and resettlement, and loss of territory and sovereignty. Legal and policy remedies seek to address such challenges by radically reframing how sovereignty is conceived. Drawing on literary and legal theory, we seek to extend such work in the terms of cultural geography and anthropology by considering how the archipelago and cultural practices known as fenua could be deployed as symbolic and material resources emphasizing mobility and connection, in contrast to normative ideas of sovereignty, whose orientation to territory imperils atoll states. Our fundamental argument is that legal and policy reforms addressing climate change emigration must be enriched by accounting for the emotional geographies that attend the changing real and conceptual borders of sovereignty and by creating alternative spaces of hope and action.
\end{abstract}

Keywords: archipelago; climate change; emigration; fenua; sovereignty; Tuvalu

(C) 2013 Institute of Island Studies, University of Prince Edward Island, Canada.

\section{Introduction}

Now would I give a thousand furlongs of sea for an acre of barren ground, long heath, brown furze, anything. The wills above be done! but I would fain die a dry death (Gonzalo, Shakespeare, The Tempest, Act I, Scene 1).

Tuvalu is a Pacific atoll nation whose member islands are its capital of Funafuti, and Nanumea, Nanumaga, Niutao, Nui, Nukufetau, Nukulaelae, and Vaitupu. Excepting Niulakita in the south, which traditionally has been uninhabited, even the name of the country includes all the individual islands in a national collectivity: Tuvalu means 'eight standing together': composed of $T u$ meaning 'to stand' and valu, signifying 'eight'. This compound noun invokes a unitary sovereignty, stable federation and place. It also invokes a people, the Tuvaluans. Their primary 
emotional geographies of nationhood - that is, their collective sense of identity and belonging as a sovereign group - are focused upon the provisional entity that is the archipelago and upon the risks and changes to which it is or will be subject (on which, see, for example, Fluri, 2011; Lupton, 2012; Park, 2010).

As a relatively new nation-state, and one of the smallest in the world, Tuvalu has achieved remarkable social and economic stability, proving to some degree that 'small is viable' according to the usual national metrics (Finin, 2002). However, confronted now with impacts of climate change which threaten the very territory that supports nationhood and delineates sovereignty, how can Tuvalu help us to think differently about sovereignty, nation, state, and emigration in the face of contemporary climate challenges? In the last decade, Tuvalu has come to stand for several interrelated crises involving climate change, sea level rise, and the twin prospects of forced emigration and resettlement and loss of sovereignty by dint of loss of territory. The international focus on Tuvalu and other island communities facing the effects of climate change has been intense (on which, see Lazrus, 2012). Such attention risks the reduction of such places and their peoples to a use value and, in this respect, catastrophizing narratives of inundation, flight, and loss have been seen as singularly unhelpful by Tuvaluans (Farbotko \& Lazrus, 2012).

In this context, welcome insights derive from papers presented in May 2011 at a seminar at Columbia University in New York. Reporting on the meeting, Legal Implications of Rising Seas and a Changing Climate, Nathaniel Gronewold (2011, no page) noted in particular that vulnerable coastal and island nations' representatives were provided some hope in the form of work by jurisprudence scholar Maxine Burkett (2011). In recent times, she has been working to demonstrate the feasibility of the Nation Ex-Situ, a category of sovereignty that could provide for ongoing existence and new forms of national government where countries' land-based territories are lost to rising tides.

Specifically, Burkett (2011, p. 346) defines ex-situ nationhood in the following terms:

... a status that allows for the continued existence of a sovereign state, afforded all the rights and benefits of sovereignty amongst the family of nation-states, in perpetuity. It would protect the peoples forced from their original place of being by serving as a political entity that remains constant even as its citizens establish residence in other states. It is a means of conserving the existing state and holding the resources and wellbeing of its citizens - in new and disparate locations - in the care of an entity acting in the best interest of its people. In practice, this would require the creation of a government framework that could exercise authority over a diffuse people.

We return more fully to Burkett's work later in the paper, since it illustrates the central importance of emotion and sense of place in these deliberations, and is key to our own considerations. Two conundrums are prompted by our reading of her ideas that need to be aired before we proceed.

First, the manner in which territory is understood in the terms set down in the Treaty of Westphalia of 1648 has translated poorly into the Pacific, arguably because for the most marginalized sovereignty and territory are "driven by the primacy of economic interests and not by non-economic rights or a conception, however broadly, of justice" (Badrinarayana, 2010 b, p. 258). To a large degree, the present meanings of sovereignty and statehood are contained and constrained by the legacy of the Treaty and consequential instruments, such as the Montevideo Convention on the Rights and Duties of States (United Nations, 1933). Article 
1 of the Convention provides that "The State as a person of international law should possess the following qualifications: (a) a permanent population; (b) a defined territory; (c) government; and (d) capacity to enter into relations with other States" (np). Thus, when territory that comprises the land-based totality of a nation-state disappears, whither sovereignty and sense of place-based identity? We pose that question, as have othersincluding Tuvaluans - aware of the existence and different and specific purposes of sovereign rights ${ }^{1}$ over the exclusive economic zone and continental shelf (Brilmayer \& Klein, 2001), and cognizant of efforts on the part of organizations such as The Seasteading Institute. Its focus has been to prove feasible various models of enduring, independent and radically libertarian ocean community and settlement for its highly privileged members. ${ }^{2}$

Attention to this first conundrum may help us to think more broadly about sovereignty and territoriality. Some scholars propose that nationalism among developing countries has a distinct character; for example, that it is idiomatic of enlightenment ideals (Chatterjee, 1986) or that it is received (rather than fought for) and is bestowed in the likeness of more "hard earned" forms of nationalism in earlier periods (Anderson, 1983, p. 160). Some argue that it is anachronistic to refer to formerly colonized people and places as nations at all (Gupta, 2003). In the Pacific, nationalism may have yet another layer of difference where it is less about "affirmative patriotism" and more about a "collective imagining [that] ... is deeply consequential for the ways in which people understand their biographical locations and attach value to a variety of practices" (Otto \& Thomas, 1997, p. 1). In this way, it is possible, at least in part, to understand sovereignty in Tuvalu as an emotional geography performed through interactions between people and place mediated through nationality and the nation-state.

Second, for Pacific peoples, the ocean is a profoundly important cultural and ontological marker and central material component of daily life that ironically now imperils that life. Hau'ofa's sea of islands proposal - that islander communities are not isolated, small, and dependent but rather are resourceful and deeply globally connected by virtue of the water surrounding them - situates national identities within a larger regional context (Hau'ofa, 1993; Lazrus, 2012). Tuvaluan people spend a significant proportion of their time on or in the ocean as fisherfolk and commercial mariners, and across island borders all are connected by it and by different registers of fenua. A set of customary practices and territorial markers, fenua captures the ways in which Pacific community identity is usually linked to part of an island - such as a valley or bay - and explains the biographical location of identity in place. Fenua is a term that indistinguishably bundles together community/people/places. Such attachments are common among 'sea peoples'; indeed Dening (2007, p. 288) describes such connections as concerned with what it means "to walk a boundary with measured step; to circumnavigate; to envelop a space with knowledge and human spirit"- to encompass.

\footnotetext{
1 Brilmayer and Klein (2001, p. 703) state that "Distinctions are made in the law of the sea between "sovereignty", "sovereign rights," and "jurisdiction" whereby each term connotes what powers a state may exercise in a particular maritime zone. "Sovereign rights" over the exclusive economic zone and the continental shelf are rights for specific purposes and thus do not permit a state to exercise full powers over these areas, as "sovereignty" might allow. No such distinction is made with respect to a state's rights over land territory".

2 The Seasteading Institute seeks to appropriate "the very medium through which capitalism and globalization have grown: the maritime world that is idealized as a frictionless surface of choice, freedom, and boundless mobility and opportunity" (Steinberg, Nyman, \& Caraccioli, 2012, p. 1542). The irony is not lost on us that we may also be idealizing that world and its stated offerings for contrasting ends that serve the marginalized.
} 
How, then, 'to encompass differently' by rethinking sovereignty under conditions of climate change emigration in ways that account for the mobile emotional geographies of island places and peoples (Farbotko \& McGregor, 2010; Stratford, 2012)? This term, emotional geographies, has been contextualized by Anderson and Smith $(2001$, p. 7$)$ in their reflections on the "extent to which the human world is constructed and lived through the emotions" and the ways in which they had "been forced to confront the glaringly obvious, yet intractable, silencing of emotion in both social research and public life". Anderson and Smith suggest that significant insights are to be gained by acknowledging that at "particular times and in particular places, there are moments where lives are so explicitly lived through pain, bereavement, elation, anger, love and so on that the power of emotional relations cannot be ignored (and can readily be appreciated)" (ibid., emphasis added). In considering such emotional geographies in the context of climate change emigration, we are also indebted to Bergmann and Tore $(2008$, p. 1) who posit that place is both a trajectory and nomadic when considering mobility's existential dimensions. They ask: how are the "risks of mobile (in)security distributed?"

Noting these points of view, our first task below is to reflect on key ideas about fenua ${ }^{3}$ as a resource to preserve and enrich both national and intra-national identities. Tuvaluan society is deeply affected by ideas of fenua and Tuvalu is one of the few Pacific places where communities map identity to an island as a whole. Then, recalling that the etymology of the term archipelago refers to an expanse of water (a chief sea) through which are scattered island groups or chains, we focus on how readings of that form are deployed by three literary scholars: Antonio Benítez-Rojo, Elizabeth McMahon, and Elizabeth DeLoughrey. To us, their works suggest strong parallels with fenua, invoke both place-based relations and mobility, multiplicity, and interconnection, and are of interest us here for two reasons. First, we read them as significant in the geohumanities, in which the present work is broadly based, because this positioning enables us to think through the archipelago as an emotional geography; this is because the geohumanities are a cross-disciplinary praxis concerned with what it is to map, reflect, represent and perform (Cosgrove, 2011; Daniels, DeLyser, Entrikin, \& Richardson, 2011; Dear, Ketchum, Luria, \& Richardson, 2011). Second, and with specific reference to Tuvalu, we posit that the archipelago and the fenua are entangled in diverse subjectivities and constitute various ways of mapping and understanding identity in place. Reference to BenítezRojo, McMahon and DeLoughrey assists our thinking and injects new meaning into their works, singly and in juxtaposition.

Building on these earlier sections, our final task is to examine narratives of emigration as a form of flight from inundation of territory. We seek to unsettle representations of Tuvaluans as refugees without capacity for sovereign self-determination, set adrift from their singular nation-state and its disappearing atolls. This work engages again with that by Maxine Burkett through which we speculate about the productive commonalities and intersections among archipelacity, fenua, and the Nation Ex-Situ. In particular, we are drawn to Burkett's synthesis of ideas about the diaspora as a "politically transformative space where legal boundaries matter less than transcendent solidarities" through which it is possible to conceive "of a viable nation-state that is both dispersed and deterritorialized" (Burkett, 2011, p. 359; emphasis added).

\footnotetext{
${ }^{3}$ Paton (2009) refers to the following: Fakanofonofoga o fenua - Traditional structures; Loto fenua community-hearted; Tagata fenua - People of the land; Te sina (o fenua)/Taupulega — (Male) elders (of the land); and Ulu aliki/Pule fenua/Tupu/Ulu fenua - High chief.
} 


\section{Considering fenua}

Communities are to be distinguished not by their falsity/genuineness, but by the style in which they are imagined (Anderson, 1983, p. 6).

Outside its borders, Tuvalu is rarely understood as anything other than a homogeneous nationstate. That sense of the singular entity is not particularly surprising: despite each of its several atolls having a distinct identity, dialect and, in one case, language, ninety-eight per cent of the population identify as Tuvaluan and are culturally similar. To some extent, the unified vision of Tuvalu - reflected in the name meaning 'eight standing together' - is a product of the country's colonial history. In 1915, Tuvalu (then known as the Ellice Islands) became a British protectorate together with neighbouring Kiribati (then known as the Gilbert Islands). The unification between the two island groups was unstable, owing first to different cultures (IKiribati are Micronesian while Tuvaluans are Polynesian) and second to colonial policies and practices in the respective island centres. Then, in 1974, with political independence from Britain on the horizon, Tuvaluans voted nearly unanimously for, and achieved, separation from Kiribati prior to independence, which came on 1 October, 1978. Arguably, it was this historical and deeply identity-affirming process that contributed to a unified sense of Tuvaluan nationality internally and especially the homogeneous nation-state as viewed from afar (Finin, 2002; MacDonald, 1975; McIntyre, 2012).

Fenua has been elemental in the emergence of sovereign identity and filial loyalty to the nation. On one hand, fenua serves to uphold a persistent impression of a stable relationship between 'people' and 'island'. On the other hand, limiting a fenua to the territory of the island from which it takes its name actually belies the importance of mobility and migration. We think it important to hold both stability and mobility open and productive, viewing them as conceptual and material resources: as cultural frameworks that could enrich the reform of legal and policy structures and systems. Indeed, as Chambers and Chambers (2002, p. 156) insist, it is crucial to understand that on and off island fenua forms "the context within which the ongoing challenges and dialectics of community life are acted out". For example, a significant and active segment of each of the island communities lives on Funafuti, the capital, attracted by jobs and services. Still, members of that diaspora retain their home-island fenua identities, while making room for hybrid forms; for example, internal migration from the island of Nanumea has seen the rise of a 'Nanafuti' identity, a form of self-identification and social organization among Nanameans on Funafuti even as they continue to observe tuu NanumeaNanumean customs. This dual commitment is exemplified by a project begun in the early 1990s to compile a fakavae-cultural constitution-highlighting unique customs among Nanumeans (Chambers and Chambers 2002). Such impulses are repeated on Funafuti among residents from the other islands in the archipelago.

Scales above the national territory are additionally important in maintaining Tuvaluan social identities, especially in the context of migration. Across the Pacific there are "structures of feeling that bind people to geographical units larger or smaller than nations or that crosscut national boundaries" (Gupta, 1992, p. 64). For instance, the small number of Tuvaluan families that have migrated to the Solomon Islands call themselves 'Solovalu' (Farbotko, personal observation). Thus the archipelago's mobile inhabitants have multiple and overlapping identities, on the basis of circumstance, combining the island of their family's land rights, the Tuvalu archipelago at large and, where relevant, their new places of residence - at least some of which, more or less obviously, are also archipelagos such as New Zealand and Australia. 
In fact, Tuvaluans tend to maintain strong links to their island communities wherever they happen to be in the world: travelling as workers on commercial ships, living on Funafuti or in New Zealand (where a Tuvaluan population numbers several thousands), and in Fiji, Australia, North America and elsewhere. In the twenty-first century, social media have been used extensively to maintain connections to family and fenua, sustaining significant relationships across vast geographic distances. Cultural practices of competition and compromise within and between island communities are central to political, economic, and social affairs in Tuvalu. Seats in the national parliament are distributed among citizens of the eight islands. Each community has its own annual day of feasting and faatele - a celebratory collective activity involving a combination of costume, song, dance, and percussion performed as a competition between villages. These celebrations are conferred by the national government as public holidays for fenua communities, so that working days throughout the year are partly determined by the island community to which one belongs.

Diaspora communities mark such celebrations by hiring local halls and serving traditional foods, often sent from relatives in Tuvalu. The faatele are highly energetic, affective performances involving a large proportion of each community as either participants or spectators. Dating from the pre-colonial period, faatele are accompanied by feasts prepared by community members. Such celebrations contrast with more staid Western-style independence day ceremonies, replete with flag-raising, marches by school children, seafarers, and police, and speeches made by the Governor General and Prime Minister (see also Finin, 2002). These national events are often attended by community leaders invited from across all the island communities, as well as by government officials and present foreign dignitaries, but do not involve extensive participation by members of the community at large. On the other hand, Independence Day draws together Tuvaluan communities in at least three of Australia's larger state capitals of Sydney, Brisbane, and Melbourne; this is partly a function of the small but relatively significant migrant populations in these cities, and partly arises from a need to celebrate solidarity rather than difference in the diaspora.

\section{Considering the archipelago}

We discover that ... the ocean is not, as generally assumed, a void or an emptiness to contrast with the 'fullness' of life on land, but rather promotes another, interrogative and critical space (Chambers, 2010, p. 1).

In conceptual terms, a chain of islands in expansive seas invites consideration of the radically decentering properties of moving oceans and shifting island boundaries, pushing the form of the island beyond singularity into multiple, interconnected and mobile configurations. ${ }^{4}$ Thus understood, the archipelago is entangled in diverse emotional geographies, and constitutes various ways of mapping, tracing or inscribing identities and geopolities.

In focusing on the real and imaginary geographies of the archipelago, we posit its value as a mode of thinking about collectivities (including those pertaining to the emotional geographies of sovereignty) to challenge two overworked topological relations between islands and mainlands/continents (for example, Harwood, 2011). One set of relations, that between land and water, positions islands as insular monads inevitably isolated from all else by the vast

\footnotetext{
${ }^{4}$ We note and welcome the advent of a discussion on other ways to conceive of these relations, including in terms of a neologism, the aquapelago (Dawson, 2012; Hayward, 2012).
} 
expanse of the sea (McMahon, 2003). The other set of relations situates mainlands (and especially continents) as necessarily superordinate and privileged because of their real and figurative mass (Baldacchino, 2008). Such ideas of singularity and dependence are deeply unsettled by acknowledging the existence and operation of horizontal and interconnected relations between islands and islanders. Possibilities for island futures based on narratives other than those of annihilation may be revealed by studying those other relations and the ways in which they articulate with stories and practices of migration. Our suggestion is that these conceptual exercises could be powerfully constitutive of how mobile, deterritorialized and reterritorialized island futures are conceived, and could aid in the task to ensure that islanders are not relegated to stateless mendicants should rising seas up-end their capacities to remain in their homelands.

Such emergent speculations on our parts are influenced by and, in turn, may be used to augment and refresh three emancipatory narratives about island chains by Antonio BenítezRojo, Elizabeth McMahon, and Elizabeth DeLoughrey. Noting the central importance of connection and fluid relations among sea peoples, each writer first refuses to see as definitive the land-sea boundary and then reconstitutes that boundary as shifting, fractal, and paradoxical. In our reading, these acts of reframing unsettle normative ideas of sovereignty and invite consideration of the Nation Ex-Situ in ways that invoke fenua.

\section{Repeating islands}

In describing the Caribbean as a bridge connecting North and South America, Benítez-Rojo (1996, pp. 2-3) constitutes that archipelago both as an assemblage enabling movement and as a field of observation. He views the region in terms borrowed from chaos theory: a space of endlessly heterogeneous and unpredictable reiterations that provides "an opening upon unexpected corridors allowing passage from one point to another in the labyrinth ... processes, dynamics, and rhythms that show themselves within the marginal, the regional, the incoherent ..." (ibid., p.3). Benítez-Rojo attempts to reconcile land and sea in terms of 'tidalectics', after Kamau Brathwaite, exposing how the Caribbean is "saturated with messages" (ibid.) including those about its "contingency and impermanence; its syncretism" (Brathwaite, 2004, p. 2). Benítez-Rojo's sense is that there exist variously echoing 'Caribbeans', which he then reveals by means of a certain kind of reading of flux, transition, and change, especially as these pertain to the fleet and the plantation. The fleet is deemed a 'machine of machines' (Deleuze $\&$ Guattari, 1983); an assemblage to produce the fluid geographies and geopolitics of empire using naval, military, bureaucratic, commercial, extractive, political, legal and religious apparatuses "installed in the Caribbean Sea and coupled to the Atlantic and the Pacific" (Benítez-Rojo, 1996, p. 8). Benítez-Rojo also refers to the plantation, another "machine of machines, ${ }^{5}$ as important as the fleet, and aided by it to use up ten million slaves from Africa and several thousand coolies from Malaysia, China and India. Together, the fleet and plantation helped forge mercantile and industrial capitalism, and effect imperialism, war, colonialism, and underdevelopment. For Benitez-Rojo, as a key site of their legacy, the Caribbean is boundless and without epicentre. It ceases to be a specific material geography of set latitude and longitude, and becomes "a cultural meta-archipelago ... [a chaos] ... within which there is an island that proliferates endlessly, each copy a different one" (ibid., p. 9).

\footnotetext{
${ }^{5}$ It occurs to us that climate change is a chief effect of another machine of machines in the guise of the carbon economy.
} 
Acknowledging the different histories of Caribbean and Pacific peoples, nevertheless we find utility in both Benítez-Rojo's scepticism about nation-building as an exercise of the West, and his observations about how Caribbean peoples have resisted displacement "by external territorializing forms ... to coexist with them through syncretic processes" (BenítezRojo, 1996, p. 20). His insights latch on to others advanced, for example, by Finin (2002, p. 28) who considered the ways in which Tuvaluans navigate increasing exposure to forces of globalization that "continue to bring to the islands' shores the perils of transnational flotsam". Noting Tuvaluans' exposure to these homogenizing dangers, which partly result from embracing certain of the apparatuses referred to above, Finin suggests that their capacity to avoid cultural displacement may principally stem from the galvanizing power of the Tuvaluan National Church. We additionally posit that fenua-and the emotional geographies it produces - has been another chief tool of syncretism and one of the primary mechanisms by which Tuvaluans have maintained both national and inter-island identities.

\section{Trinkets in a chain}

By reference to island-Australia, but in ways that we think apply to Tuvalu's archipelagicity, Elizabeth McMahon (2003, p. 192) quotes Deleuze on the monad, thus: "As an individual unit each monad includes the whole series; hence it conveys the entire world, but does not express it without expressing more clearly a small region of the world, a 'subdivision,' a borough of the city, a finite sequence (Deleuze, c.1993, p. 25)". McMahon considers the island-continent in terms of the analagon, chains of signification, and the chiasmus - a term describing a pattern of expression in which the second half is balanced against the first with the parts reversed-an island state // a state of islands is one such example. In the process, McMahon underscores the integral functions of the island utopia. The first-magnification-enables concurrent consideration of the Torres Strait archipelago, its island continent 'mainland' of Australia, and the world as island; parallels are possible in terms of each of the islands in Tuvalu, the nationstate itself, and the manner in which it has come to stand for the fragility of island-Earth.

In McMahon's reading of the chains of signification of island-Australia, a second function that resonates in relation to Tuvalu becomes apparent: the idea of islands as simultaneously connecting and separating. If the island utopia is a metonym for the world in miniature - secure and absolute inside its borders - each island is sovereign, "a world unto itself" (McMahon, 2003, p. 192) and that is deeply reminiscent of fenua, which we have interpreted as mobile and, while neither secure nor absolute, is also and decidedly not trapped or condemned to a particular fate. In such light, McMahon suggests that thinking about islands be reformulated as part of a larger postcolonial project to unsettle the staging of the nation; in the process, islands must not be seen as mere trinkets but as monads "within the space of an archipelago" (p. 201). Thus understood, they convey the world in terms of innumerable regions, sequences, and nuances. From such foundations, McMahon reflects on processes of romanticization and the celebration of 'my island home' as rendered in song at the 2000 Sydney Olympic Games closing ceremony by Christine Anu, a prominent entertainer and Torres Strait Islander. McMahon demonstrates how such a representation of the Australian coast and centre has implications for conceptions of sovereignty and nation. In telling fashion, she describes how the hyperbole of the Games was replaced in 2002 by manoeuvres to excise the Torres Strait Islands. Those manoeuvres ultimately embraced Christmas Island, Ashmore and Cartier Islands, Cocos (Keeling) Islands, and other external territories and islands forming part of the states and territories as excised spaces and thus prescribed in the regulations of the 
Migration Amendment (Excision from Migration Zone) Act 2001. They limit access to Australia by those termed refugees, asylum seekers, or illegal immigrants. Given possible futures involving climate change, these points are clearly important.

McMahon underscores the point that Australia's offshore islands are a "source of grave insecurity" and "extreme vulnerability" (p. 194); so too the islands of the Pacific. These are sites from which flow to mainland Australia people of apparently untested standing and alleged capacity to harm its sovereignty, economy, and political stability. In such understandings of imminent threat, Australia is rendered a closed and still monolith rather than an open and mobile island group; this rendering, of course, is moot, given that the nation (via the Royal Australian Navy, for example) continues to reach outside the nation, not abandoning those imperilled refugees as they try to reach the excised monad. ${ }^{6}$ In her section of a collective review of such matters in work by Suvendrini Perera (2009), McMahon later points out that asylum seekers have been demonized and misrepresented (in Stratford, McMahon, Farbotko, Jackson, \& Perera, 2011). Such processes of rejection and distortion recast the 'island home' as an unsettled and risky place in which one is overwhelmed by the Other, and they do nothing to aid sensitive debate about how to prepare for climate change emigration and resettlement.

\section{Watery webs and networks}

Elizabeth DeLoughrey (2001, p. 23) writes that "a system of archipelagraphy — that is, a historiography that considers chains of islands in fluctuating relationship to their surrounding seas, islands and continents - provides a more appropriate metaphor for reading island cultures". Noting her debt to writers such as Edouard Glissant, Epeli Hau'ofa, and Derek Walcott, DeLoughrey posits the utility of archipelagraphy for mapping the "complex ebb and flow of immigration, arrival, and of island settlement", especially given the record of past and present exploitation of island places, peoples and resources.

DeLoughrey (2007) later grounds her exploration of islands and archipelagos by reference to Earth as a 'terraqueous globe' in which all landmasses are islands in some sense, and this echoes the point we made in relation to the Torres Strait when responding to McMahon's ideas, above. DeLoughrey underscores the pull of the sea in understanding human origins, and emphasizes its radically decentering capacities. For her, a focus upon "seascape rather than landscape as the fluid space of historical production allows us to complicate the nation state" (ibid., p. 21) is equalizing, and gives voice to histories other than European and colonial. Moreover, this analytical strategy enables the juxtaposition of physically distant island regions, such that dialogue between them is possible and enables "us to see the complex historical relationships to the waters that surround them" (p. 22). With respect to Tuvalu, the power of what DeLoughrey describes as aquatic and sinuous folds and double folds of waves and currents is clear here: these are watery webs of networks, of flux, of space beyond territorialism and of great conceptual utility. Drawing on Carolyn Merchant's (1980) masterpiece, The Death of Nature, DeLoughrey (2007, p. 15) posits that "colonial powers fetishize what they have effectively destroyed". She maps the trajectory of this impulse by examining in tandem "oceanic discourse at the end of the nineteenth century with its contemporary counterparts" to suggest that "the rise in naturalized images of transoceanic diaspora derives from increased maritime territorialism" (ibid., p. 30). DeLoughrey's focus is

\footnotetext{
${ }^{6}$ For this astute observation we are grateful to Elizabeth Jones, PhD Candidate, School of Geography \& Environmental Studies, University of Tasmania.
} 
on the United Nations Convention on the Law of the Sea (United Nations General Assembly, 1982) and on Elizabeth Mann Borgese's work from 1993, in which the latter observed that the UNCLOS created a new economic order, economic philosophy, and human/non-human/morethan-human relations. The UNCLOS also

sanctioned the concept of archipelagic waters, crucial to island nations in that it invested them with greater jurisdiction to protect and manage seaborne traffic, fish harvesting, and pollution ... This was a literal and cartographic remapping of presumably isolated isles into a 'sea of islands'... mare nostrum, 'our sea', represents a transnational agreement of mutual participation, conservation, and obligation (DeLoughrey, 2007, pp. 32-3).

In the process, the UNCLOS required a radical remapping of the Earth to account for the alterity of the oceans (and in passing we speculate that such reinscriptions may yet again be required throughout this century). UNCLOS expanded sovereignty for coastal nations out to 12 nautical miles [22km] and contiguous zones to 24 nautical miles [44km], and created Exclusive Economic Zones (EEZ) of 200 nautical miles [370km] whose area for Tuvalu amounted to some 38 million nautical square miles $\left[70,376,000 \mathrm{~km}^{2}\right]$ of heavily contested ocean space. That contestation is likely to continue.

\section{Considering climate change emigration and the promise of the nation ex-situ}

We now consider the implications of wholesale emigration from atoll nation-states and ask what possibilities for new forms of sovereignty emerge by 'thinking with the archipelago and fenua' given that there appear to be few if any "adequate mechanisms under international law to balance the competing tensions climate change presents to state sovereignty" (Badrinarayana, 2010a, p. 255). Such tensions are illustrated by a common account of Tuvalu and other island places as chains of islands submerged, their peoples displaced, lost, or removed. This story is one we have sought elsewhere to unsettle, all the while puzzling over its persistence and the fascination - particularly in the West - with tales of a few slips of sand in the Pacific disappearing beneath the waves (Farbotko \& Lazrus, 2012; Stratford \& Langridge, 2012). Variations of this story promulgated by others 'on behalf of' Tuvaluans seem always to have a tragic finale: the islanders drown, starve or die of thirst, or they are lifted, destitute, to new places, receiving little help from their fellow world citizens in terms of restitution and substantive legal and financial remedies for their loss of land, nation-state and sovereignty. Erroneously and in extremis this narrative is one of extinction.

Alternatively, there is urgent need to be open to other perspectives, including those produced by Tuvaluans. This point has been effectively made by indigenous research students whose studies present two arguments. First, there is significant divergence of viewpoint between Tuvaluans and external actors, including policy-makers, scholars, scientists, and donors. Second, climate change adaptation and mitigation are best advanced in terms of local interpretations of local issues (such as those about kinship, spirituality and community, for example) as well as local understandings of wider, indeed global, dynamics of economic development, or migration, or climate change (Lusama, 2004; Niuatui, 1991; Simati, 2009). Indeed, in Tuvalu as elsewhere among island nation-states, emigration has become a key conversation in response to climate change; increasingly, it is positioned as a key strategy by 
which to rewrite the catastrophizing narratives of island(er)s drowned. This narratological function of emigration has been more commonly constituted as a key development strategy.

A chief means to engage in inter-island and international economic activities, migration's putative benefits include the return of remittances home", and this 'economic development' strategy augments others, most notably the attraction of aid from donor nations and the creation of large bureaucracies at home. States using this composite approach have been described as MIRAB (Migration, Remittances, Aid and Bureaucracy) economies (Bertram \& Watters, 1985). Among such economies are islands and archipelagos 'remote' from core and/or densely populated centers, although we note that the two are not mutually exclusive, as evinced by reference to Tuvalu's capital island of Funafuti, on which reside nearly 4,500 people, as enumerated at the 2002 census.

In relation to fenua's mobility, the fluidity of the idea of the archipelago, and the pragmatics of emigration, there is aptness to Baldacchino's (2006, p. 6) suggestion that "ceteris paribus, the smaller the territory and the higher the population density of its inhabitants, the more likely is it that its footprint extends beyond its shores". Baldacchino's remark acts as a counter-argument to stories of vulnerability insofar as small island communities exhibit great jurisdictional resourcefulness and actively shape their fate, viewing extra-territorial activities as mechanisms by which to extend their hinterlands. Migration is one such activity (Baldacchino, 2010; Bertram, 2006); we posit that another would be to deploy the archipelago and fenua as conceptual resources in more seriously acknowledging, and considering, the emotional geographies of sovereignty.

But: does migration function in this resourceful manner in relation to climate change, or does it constitute islanders as 'climate change refugees', ill-fated and inevitably without sovereign status and identity? This question is brought into focus by the differential framing of climate change. For example, Mortreux and Barnett (2009, p. 110) note that Tuvaluans confront many problems as citizens of a 'least developed country', among them "poor housing, inadequate sewerage and waste disposal, unemployment, nutrition-related health problems and under-resourced health services". Under such circumstances, there is a tendency to discount future problems, including climate change, whose effects are often intangible and distant. Not surprisingly, Mortreux and Barnett report that Tuvaluans dismiss wholesale climate change emigration as a last option, not least because it may entail loss of sovereignty and identity.

While Tuvalu is indeed a sovereign nation, at the same time it is eight functionallydistinct communities. In this light, Simati $(2009$, p. ii) notes that:

[the] benefits of long-term migration can only be sustained as long as loto fenuaisland loyalty — and family kinship stay intact across borders, and networking amongst families, communities and church remains active.

\footnotetext{
${ }^{7}$ Remittances have been a feature of Tuvaluan life since the beginning of the twentieth century (Munro, 1990). Census statistics indicate that 47 per cent of Tuvaluan households receive remittance income regularly, and for 18 per cent of households remittances are the main source of income; 56 per cent of all remittances are received from outside Tuvalu. Tuvaluans working in New Zealand were surveyed in 1998 (Simati \& Gibson, 2001) in a study that argued that long term continuation of remittances among Tuvaluans there is likely, the authors finding that remittances appeared to rise for 30 years after a migrant has arrived in New Zealand.
} 
This observation is critical for our purposes because it raises the possibility that fenua could be deeply compromised by emigration if the emotional geographies that constitute it are not better understood. For us, it also requires thought about whether that movement of people offshore is for work, education and training, or part of an irrevocable exodus from lands no longer habitable; loto fenua takes on vastly different complexions depending on the answer and on how sovereignty is framed.

Here, we return to Maxine Burkett (2011) whose premise is that the loss of land forecast to be part of climate change presents an unprecedented set of challenges for international law, and whose solution is the idea of the Nation Ex-Situ, described earlier. Burkett defines this form of nationhood as a trusteeship system by which to administer the duties of a deterritorialized government. She acknowledges certain impediments to her solution, not least among them investments in the idea of the law as consistent, coherent, universal and predictable. In return she proposes that climate change so fundamentally affects our systems of law and governance, and argues that "flexibility, individual application, and responsiveness" (ibid., p. 347) are essential. Such is especially the case for small island communities, which will be "absent a country-with all its attendant legal, economic, and cultural markers" (ibid., p. 348), but it ramifies out to unsettle the very underpinnings of the Westphalian system, presently typified by what Burkett terms political lethargy in relation to climate change emigration. Would fenua also extend in this way beyond the structures of the Westphalian defined small island state?

Critically important for our own speculations about the utility of thinking about the emotional geographies of climate change emigration, and about the usefulness of the archipelago and fenua as material and symbolic resources, Burkett posits the imminent flexibility of statehood as a concept. Citing the Papal See, governments in exile, Tibet, the European Union, and Taiwan as different exemplars of this plasticity ${ }^{8}$, she draws on ideas about cosmopolitan citizenship and its capacity to enable different refugee regimes with expanded rights. Additionally, anticipating our own concerns about whether land is an originary prerequisite for fenua, Burkett emphasizes the importance to Pacific peoples of their roots in place, but argues that a "virtual nation-state, held together by a social network [and political framework based on the trusteeship], may help ease the rootlessness that an uninhabitable territory will engender" (ibid., p. 362). She then elaborates on various mechanisms to achieve such ends by reference to an imaginary case, the Republic of Marshall Islands Ex-Situ (hereinafter RMIes). Burkett's sense is that this sovereign arrangement would "ease the devastation that will almost certainly accompany the inevitable rupture of the characteristic land-person-community bond in the Pacific" (ibid., p. 371) and in this manner links jurisprudence, international law reform, and emotional geographies. Given Burkett's earlier comments about the flexibility of statehood, we feel more confident in pressing the utility of thinking with the archipelago (implicating repetition, chains, and networks) and in terms of fenua (implicating mobile emotional geographies of nationhood).

One final example aids this argument. Consider how fenua is embodied and repeats in a cultural chain — a system of archipelagraphy - that extends between Vaitupu in the Tuvaluan archipelago and Kioa in Fiji (White, 1965). In 1946, along with the others on islands then a part of the British Gilbert and Ellice Islands Colony, the Vaitupu community collectively agreed to purchase Kioa at auction. A subsection of the population of Vaitupuans moved there

\footnotetext{
${ }^{8}$ In work on islands and enclaves, Godfrey Baldacchino (2010) makes a number of points that map onto some of these exemplars.
} 
and descendants remain today. Although Kioa is within Fiji's national territory and has no formal support from the Tuvaluan national government, its inhabitants maintain strong political, economic and kinship links with community on both Funafuti and Vaitupu. During discussions held as part of one UN climate change consultation process, the National Adaptation Plan of Action, members of the Vaitupu community suggested Kioa as a possible relocation site for Tuvaluans in the event of significant sea-level rise at home. In Kioa's favour, elevations above sea level are substantially higher than that on all the islands in the Tuvalu archipelago. Yet, the role of Kioa in the cultural dynamics of inter-fenua competition means that island communities other than the Vaitupuans may hesitate to support relocation. On Kioa, Vaitupuans' capacity to influence inter-fenua dynamics of power could be significantly altered, such that the remaining communities might feel indebted to, and thus dependent upon them. Other Tuvaluans may also see little reason to move to Kioa; for them, social networks and employment and education opportunities are likely to be greater elsewhere, especially in New Zealand. In this regard consider, too, how fenua is practised by Tuvaluan families from the northernmost outer island of Nanumea now living in New Zealand when they refer to branches of the family, and to others to whom they are not directly related, by mapping proximity and distance between ancestral lands back in Nanumea, which comes to stand as a compass simultaneously moral, socio-cultural and, by easy extension, politico-economic.

The cultural and political spaces of Kioa, Vaitupu, Tuvalu, New Zealand and the other archipelagic forms suggest that the 'fit' of climate change emigration strategies depends on complex relations at different scales, and on particular conceptions and practices of mobility and space. Policies that neglect the important decision-making functions and powers concentrated in the fenua, or that do not fully appreciate the fluid emotional and other geographies that are implied by land and sea scapes, are not likely to gain strong support from the various Tuvaluan communities; nor is any approach that does not result in equitable outcomes for island communities. On the other hand, transnational fenua connections are likely to be of assistance to future migrants. Accounting for such dynamics occurs on a daily basis in all types of decision-making in Tuvalu, but is nearly absent in international and regional legal and policy-making circles; and we confess that we do not presently know how they might, in any case, be taken up given the proclivities of western law and policy. Notwithstanding this current uncertainty, we are convinced that it is short-sighted to ignore the particular emotional geographies of nationhood in thinking about climate change, emigration and sovereignty that are present among island and archipelagic peoples.

\section{Conclusion}

We began this paper by reference to $T u$ - and valu- or eight standing together: a stable federation, place and people. Tuvalu is also a low-lying atoll nation-state, and under climate change scenarios Westphalian forms of sovereignty serve such land-and-seascapes poorly because they are oriented to economic rather than political ends and provide no incentives for emission reduction or forms of moral extensionism that are urgently needed.

Alongside a small number of similar island and coastal states, Tuvalu now stands for several interrelated crises highlighting the prospect of emigration and resettlement and loss of sovereignty and territory. The predicted eventual inundation of the landmasses that currently comprise Tuvaluan national territory is widely known and highly sensitive. We have argued that, in working compassionately with such sensitivities, it would be helpful to find new ways to speak about and represent climate change impacts-including their emotional geographies. 
In that respect, we welcome scholarship on the Nation Ex-Situ, which could provide for ongoing existence and new forms of national government where countries' land-based territories are lost to rising tides and emigration becomes essential.

We have also proposed that legal reform is necessary but insufficient, and confirm Burkett's argument that sense of place, community, and connection must be accounted for in any such reform. In our estimation, there will be utility in deploying fenua and the archipelago as conceptual resources for such ends: these are already powerful symbolic and material properties of island. We speculate that the concepts we have aired, apt for the case we have outlined, can themselves 'travel'; may be applied elsewhere by others to aid the task of understanding the emotional aspects of emigration and reforms to sovereignty that have been the focus of our analysis; and could be taken up by others concerned with these matters. In particular, fenua provides the capacity to map identity to an island as a whole, and invokes place-based relations and mobility, multiplicity, and interconnection. The archipelago holds object lessons for thinking about the monad and chiasmus, which conveys the world in terms of interrelated regions, sequences, and nuances. And the archipelago invites consideration of an allied idea in the form of archipelagraphy: chains of islands in fluctuating relationship to their surrounding seas, islands and continents. The archipelago also provides the capacity to think in terms of the bridge, enabling movement [of people, ideas, reforms, innovation]; in terms of repetition, enabling replication and reappearance; and in terms of syncretism, reconciling different and opposing elements. Not least among these are traditional notions of sovereignty as static and new ideas of its possible mobility and the resilience of those who urgently require such change.

\section{References}

Anderson, B. (1983). Imagined communities: Reflections on the origin and spread of nationalism. London: Verso.

Anderson, K., \& Smith, S. J. (2001). Editorial. Emotional geographies. Transactions of the Institute of British Geographers NS, 26(1), 7-10.

Badrinarayana, D. (2010a). Global warming: a second coming for international law? Washington Law Review, 85(2), 253-294.

Badrinarayana, D. (2010b). International law in a time of climate change, sovereignty loss, and economic unity. Proceedings of the Annual Meeting-American Society of International Law, 104, 256-259.

Baldacchino, G. (2006). Managing the hinterland beyond: Two ideal-type strategies of economic development for small island territories. Asia Pacific Viewpoint, 47(1), $45-$ 60.

Baldacchino, G. (2008). Studying islands: on whose terms? Some epistemological and methodological challenges to the pursuit of island studies. Island Studies Journal, 3(1), 37-56.

Baldacchino, G. (2010). Island enclaves: Offshoring strategies, creative governance and subnational island jurisdictions. Montreal, QC: McGill-Queen's University Press.

Benítez-Rojo, A. (1996). The Repeating Island: the Caribbean and the Postmodern Perspective. Durham, NC: Duke University Press.

Bergmann, S., \& Sager, T. (2008). Introduction. In between standstill and hypermobility introductory remarks to a broader discussion. In S. Bergmann \& T. Sager (Eds.), The 
Ethics of mobilities. Rethinking place, exclusion, freedom and environment (pp. 1-9). Aldershot: Ashgate.

Bertram, G. (2006). Introduction: The MIRAB model in the twenty-first century. Asia Pacific Viewpoint, 47(1), 1-13.

Bertram, I. G., \& Watters, R. F. (1985). The MIRAB economy in South Pacific microstates. Pacific Viewpoint, 26(3), 497-519.

Brathwaite, E. K. (2004). Words need love too. London: Salt Publishing.

Brilmayer, L., \& Klein, N. (2001). Land and sea: Two sovereignty regimes in search of a common denominator. New York University Journal of International Law and Politics, 33(3), 703-768.

Burkett, M. (2011). The Nation Ex-Situ: On climate change, deterritorialized nationhood and the post-climate era. Climate Law, 2(3), 345-374.

Chambers, I. (2010). Maritime criticism and lessons from the sea. Insights [Works in progress from the Institute of Advanced Study, Durham University], 3(9), 1-14.

Chambers, K., \& Chambers, A. (2002). Ethnographer as taker and maker in Tuvalu. In S. R. Jaarsma (Ed.), Handle with care: Ownership and control of ethnographic materials (pp. 151-173). Pittsburgh, PA: University of Pittsburgh Press.

Chatterjee, P. (1986). Nationalist thought and the colonial world: a derivative discourse. Minneapolis: University of Minnesota Press.

Cosgrove, D. (2011). Prologue: Geography within the humanities. In S. Daniels, D. DeLyser, J. N. Entrikin \& D. Richardson (Eds.), Envisioning landscapes, making worlds: Geography and the humanities (pp. xxii-xxv). London: Routledge.

Daniels, S., DeLyser, D., Entrikin, J. N., \& Richardson, D. (Eds.). (2011). Envisioning landscapes, making worlds. geography and the humanities. London: Routledge.

Dawson, H. (2012). Archaeology, aquapelagos and island studies. Shima: The International Journal of Research into Island Cultures, 6(1), 17-24.

Dear, M. J., Ketchum, J., Luria, S., \& Richardson, D. (2011). GeoHumanities: Art, history, text at the edge of place. London: Routledge.

Deleuze, G., \& Guattari, F. (1983). Anti-Oedipus: Capitalism and schizophrenia. Minneapolis, MN: University of Minnesota Press.

DeLoughrey, E. (2001). "The litany of islands, the rosary of archipelagoes": Caribbean and Pacific archipelagraphy. Ariel: A Review of International English Literature, 32(1), 2151.

DeLoughrey, E. (2007). Routes and roots: Navigating Caribbean and Pacific island literatures. Honolulu, HI: University of Hawai'i Press.

Dening, G. (2007). Sea people of the west. Geographical Review, 97(2), 288-301.

Farbotko, C., \& Lazrus, H. (2012). The first climate refugees? Contesting global narratives of climate change in Tuvalu. Global Environmental Change, 22(2), 382-390.

Farbotko, C., \& McGregor, H. V. (2010). Copenhagen, climate science and the emotional geographies of climate change. Australian Geographer, 41(2), 159-166.

Finin, G. A. (2002). Small is viable: The global ebbs and flows of a Pacific atoll nation. Pacific Island Development Series, East West Center Working Papers, No. 15 (April).

Fluri, J. L. (2011). Bodies, bombs and barricades: geographies of conflict and civilian (in)security. Transactions of the Institute of British Geographers, 36(2), 280-296.

Gronewold, N. (2011). Island nations may keep some sovereignty if rising seas make them uninhabitable. The New York Times. Business Day. Energy and Environment, 25 May. 
Retrieved from http://www.nytimes.com/cwire/2011/05/25/25climatewire-islandnations-may-keep-some-sovereignty-if-63590.html?pagewanted=all

Gupta, A. (1992). The song of the nonaligned world: Transnational identities and the reinscription of space in late capitalism. Cultural Anthropology, 7(1), 63-79.

Harwood, A. (2011). The Political constitution of islandness: The 'Tasmanian Problem' and Ten Days on the Island. University of Tasmania, Hobart.

Hau'ofa, E. (1993). Our sea of islands. In E. Waddell, V. Naidu \& E. Hau'ofa (Eds.), A New Oceania: Rediscovering our sea of islands (pp. 2-16). Suva, Fiji: The University of the South Pacific.

Hayward, P. (2012). Aquapelagos and aquapelagic assemblages. Shima: International Journal of Research into Island Cultures, 6(1), 1-11.

Lazrus, H. (2012). Sea change: island communities and climate change. Annual Review of Anthropology, 41(1), 285-301.

Lupton, D. (2012). Beyond the 'affect heuristic': the emotion-risk assemblage. Paper presented at the 'Risk and Uncertainty Plenary Session', Australian Sociological Association Conference.

Lusama, T. (2004). Punishment of the innocent: The problem of global warming with special reference to Tuvalu. Tainan City, Taiwan: Master of Arts Dissertation, Tainan Theological College and Seminary.

MacDonald, B. (1975). The separation of the Gilbert and Ellice Islands. Journal of Pacific History, 10, 84-88.

McIntyre, D. (2012). The partition of Gilbert and Ellis Islands. Island Studies Journal, 7(1), 135-146.

McMahon, E. (2003). The gilded cage: from utopia to monad in Australia's island imaginary. In R. Edmond \& V. Smith (Eds.), Islands in History and Representation (pp. 190-202). London and New York: Routledge.

Merchant, C. (1980). The Death of Nature. San Francisco: Harper and Row.

Mortreux, C., \& Barnett, J. (2009). Climate change, migration and adaptation in Funafuti, Tuvalu. Global Environmental Change 19(1), 105-112.

Munro, D. (1990). Migration and the shift to dependence in Tuvalu: a historical perspective. In J. Connell (Ed.), Tuvalu: A historical perspective in migration and development in the South Pacific (pp. 29-41). Canberra, Australia: National Centre for Development Studies, Research School of Pacific Studies, The Austalian National University.

Niuatui, P. (1991). Sustainable development for Tuvalu: a reality or an illusion? University of Tasmania, Hobart.

Otto, T., \& Thomas, N. (Eds.). (1997). Narratives of nation in the South Pacific. Amsterdam, The Netherlands: Hardwood Academic Publishers.

Park, H. (2010). Heritage tourism: emotional journeys into nationhood. Annals of Tourism Research, 37(1), 116-135.

Paton, K. L. (2009). At Home or abroad: Tuvaluans shaping a Tuvaluan future. Wellington, New Zealand: Victoria University of Wellington.

Perera, S. (2009). Australia and the Insular Imagination: Beaches, Borders, Boats and Bodies. London: Palgrave Macmillan.

Simati, A. M., \& Gibson, J. (2001). Do remittances decay? Evidence from Tuvaluan migrants in New Zealand. Pacific Economic Bulletin 16(1), 55-63. 
Simati, S. P. (2009). The effect of migration on development in Tuvalu: a case study of P.A.C. migrants and their families. Palmerston North, New Zealand: Massey University.

Steinberg, P. E., Nyman, E., \& Caraccioli, M. J. (2012). Atlas swam: Freedom, capital, and floating sovereignties in the Seasteading vision. Antipode, 44(4), 1532-1550.

Stratford, E. (2012). Vantage points: observations on the emotional geographies of heritage. In G. Baldacchino (Ed.), Extreme heritage management: The policies and practices of densely populated islands (pp. 1-20). New York: Berghahn Books.

Stratford, E., \& Langridge, C. (2012). Critical artistic interventions into the geopolitical spaces of islands. Social and Cultural Geography, 13(7), 821-843.

Stratford, E., McMahon, E., Farbotko, C., Jackson, M., \& Perera, S. (2011). Review Forum. Reading Suvendrini Perera's Australia and the Insular Imagination. Political Geography, 30(6), 329-338.

United Nations. (1933). Montevideo Charter: 49 Stat. 3097; Treaty Series 881, December 26. Montevideo: United Nations Convention on the Rights and Duties of States.

United Nations General Assembly. (1982). UN Convention on the Law of the Sea. Retrieved from http://www.un.org/Depts/los/convention agreements/texts/unclos/part8.htm

White, G. M. (1965). Kioa: an Ellice community in Fiji. Eugene, OR: Oregon University Department of Anthropology. 